\title{
The Effects Of The Refugee Crisis On The EU-Turkey Relations: The Readmission Agreement And Beyond
}

\author{
Pinar Gedikkaya Bal, Assistant Prof. \\ Beykent University, Turkey
}

doi: 10.19044/esj.2016.v12n8p14 URL:http://dx.doi.org/10.19044/esj.2016.v12n8p14

\begin{abstract}
The recent refugee crisis has created a new momentum in the EUTurkey relations which have been going through an impasse in the last couple of years. With the latest EU-Turkey Readmission Agreement, the European Union's promise of visa liberalization, financial aid as well as the opening of a new chapter in accession negotiations, it has become possible to talk about a rapprochement between the two parties. This paper aims to examine the effects of the refugee crisis on the EU-Turkey relations in the light of these recent developments. The paper also aims to analyze the possibility of further cooperation and improvement of relations between the two parties as a result of this rapprochement.
\end{abstract}

Keywords: Refugee crisis, Readmission Agreement, Visa liberalization, EUTurkey relations

\section{Introduction}

With the massive influx of migrants to Europe that has reached alarming numbers in 2015, Europe has been witnessing one of the biggest refugee crisis since the Second World War. The terrorist attacks in Paris in November 2015 have exacerbated this crisis further. As the doubts about the European Union's (EU) ability to manage its common borders increased, migration has become a top priority issue for the EU.

Over the last couple of years, nurtured by the Arab Spring and specifically as a result of the Syrian Civil War, the number of refugees trying to run away from Syria and some other countries located mostly in the war torn regions of the Middle East and Africa have increased dramatically leading to a refugee crisis. This increase in the number of refugees have reached such levels that the capacities of the neighboring countries to help these people have been surpassed and by the second half of 2015, increasing numbers of refugees have started to push the borders of the EU. In the first years of the crisis, these refugees were mostly being hosted by countries like 
Turkey, Jordan and Lebanon. Especially following the brutal attacks of the Syrian President Bashar al-Assad towards his own people, many Syrians have fled to Turkey. Turkey has followed an open door policy towards these refugees fleeing from Syria. It has established refugee camps and has hosted quite a number of refugees in these camps. Therefore, until 2015, the refugees have preferred mostly to stay in Turkey where they were welcomed and supported as well as Jordan and Lebanon. During this time period, the refugees were attracting the interest of the media and civil society in Europe. However; in 2015, when the flow of refugees who were trying to reach the EU began to increase abruptly, the EU has awakened to a refugee crisis (Bayraklı and Keskin, 2015: 9).

Currently, the management of this crisis both in the domestic and in the external spheres will have vital repercussions for the EU leaders, for the future of the EU as well as for Turkey and the countries of the region. It has become obvious that the best way to stop the inflow of refugees from the Middle Eastern and African regions to the EU is to stop civil wars and internal fights in those countries and to establish democratic governments who would respect human rights and work for the welfare of their citizens. However; this is far away from being a short term solution to manage the current refugee crisis but rather a long term one. The EU can work to bring peace to those regions and help to rebuild the social and economic atmosphere which would create the incentive for their citizens to stay or even return back to their own countries. This would at first require the establishment of safe regions for these people. However, in the short term, the EU has had to use a firefighting strategy to be able to cope with this crisis. While domestically it has tried to come up with some practical policies to manage the stay of existing refugees, externally it has aimed to decrease the number of refugees trying to penetrate the EU from illegal ways. In this respect, the EU has tried to improve its cooperation with its neighbors at its borders to better control illegal migration. At this juncture, EU's recent attempts to revitalize its relations with Turkey through the EUTurkey Readmission Agreement, Visa Liberalization Dialogue, financial support and opening of a new chapter in accession negotiations attract attention and deserve analysis.

This paper aims to investigate the effects of the refugee crisis on the EU-Turkey relations. The refugee crisis has highlighted the importance of Turkey for the EU as a neighboring country. If supported, Turkey has the capacity as well as the will to host the refugees fleeing from Syria. Knowing this, the EU led by Germany has approached Turkey for the earlier implementation of the Readmission Agreement which has already been signed in December 2013 and came into effect in 2014. In an effort to convince Turkey for this agreement to be implemented at an earlier date, the 
EU has offered some incentives to Turkey in the form of financial support as well as earlier implementation of visa liberalization and has promised to open new chapters in accession negotiations. Shortly, the refugee crisis has led to a rapprochement between the EU and Turkey whose relations have shown a slow down in the last couple of years. The refugee crisis has revived the relations and the two parties have come together for a Readmission Agreement which would be supported financially and followed by visa liberalization.

In the first part of this paper, the readmission agreements as well as visa liberalization dialogues that the EU has concluded with other countries will be analyzed. There seems to be a common understanding among a large part of the Turkish public that the EU has demanded readmission only from Turkey and that this agreement has been specifically formulated for Turkey. Therefore, first the nature of EU readmission agreements will be examined, then agreements which had already started to be implemented and those which are still in negotiation will be listed. This will be done to show that readmission agreements are an important tool of EU migration policy, Turkey is not the first country to sign such a deal.

The relations between the EU and Turkey were under an impasse over the last couple of years. The Turkish public has lost its trust and faith in the EU to a great extent. Therefore, for many Turkish people, visa liberalization was just another promise that the EU might not keep anyway. In an effort to shed light on the worries of the Turkish side, in this paper, visa liberalization dialogues that have already been used as an incentive in other readmission agreements of the EU will be analyzed to see if they have been started to be implemented successfully or not.

In the second part of this paper, after a short overview of EU-Turkey relations, the recent developments in terms of the EU-Turkey Readmission Agreement, the Visa Liberalization Dialogue and accession negotiations will be described. The paper will be finalized with an analysis of the effects of these developments on the EU-Turkey relations and whether these developments could be influential to really overcome the impasse in the relations.

\section{The Refugee Crisis and the EU}

The EU's handling of the refugees has been governed by the Dublin Convention. According to this Convention, an asylum seeker applies for asylum in the country where he/she has stepped in first. As a result of this rule, the refugees who have reached the EU from its southern borders by passing over the Mediterranean have started to increase rapidly leading to a reaction in the EU especially in Greece and Italy. However, soon it has become clearly evident that the EU did not have a working and unified 
migration policy to manage these uncontrolled refugee flows. The Dublin Convention was not capable of managing or solving the current refugee crisis. Therefore, the EU's initial response to the refugee crisis has been incoherent. Different member states have taken different approaches to the problem. Some countries have introduced border controls like Denmark's decision on its borders with Germany. While Hungary has started to build a wall to stop the refugees, Poland has refused to accept thousands of refugees. As a result of these developments, the ex-President of France Nicholas Sarkozy has even called Schengen to be dead (Gönen, 2016). Across the EU, nationalism and far-right parties have started to gain increased support in parallel with increasing xenophobia and Islamofobia. In a way, the refugee crisis has turned out to be a domestic problem in many of the member states as well as a crisis for the EU as a whole. In this crisis atmosphere, the EU has given priority to security driven concerns and interests of the EU member states and has tried to come up with new policies to improve border controls, return and readmission, and fight against smuggling. Ensuring full compliance with fundamental human rights standards and principles have stayed at the second rank. (Carrera et al, 2015)

In this crisis, the existing instruments to control the external borders, like Frontex and Triton, were not effective, either (Crisp, 2015). It has become clear that the EU was not able to struggle with this crisis only by using its existing instruments and policies. For many EU politicians and leaders, the EU has limits and accepting more refugees is not economically sustainable anymore, furthermore, it risks destroying the EU (Gotev, 2015). Therefore, besides initiating policy changes and taking new decisions within the internal borders of the EU to cope with this crisis, like relocation of refugees and new financial support, the EU has decided to take immediate action to somehow decrease and eventually stop this flow of refugees. One of the most important tools used by the EU to fight illegal migration has been the readmission agreements.

\section{The Role of Readmission Agreements within the Migration Policy of the EU}

An effective return policy is a very important part of a successful migration policy. In an effort to manage returns, the EU tries to harmonize national efforts in parallel with the Return Directive ${ }^{1}$. The Return Directive establishes common standards and procedures for the return of irregular

\footnotetext{
1 DIRECTIVE 2008/115/EC OF THE EUROPEAN PARLIAMENT AND OF THE COUNCIL of 16 December 2008 on common standards and procedures in Member States for returning illegally staying third-country nationals.

http://eur-lex.europa.eu/LexUriServ/LexUriServ.do?uri=OJ:L:2008:348:0098:0107:EN:PDF (Accessed on: 19.01.2016).
} 
migrants. This legislation is under the Schengen acquis. To make the Return Directive efficient, it is necessary to cooperate with the non-EU countries. This is being achieved by the readmission agreements (European Commission, 2015a).

The readmission agreements aim to facilitate the return of third country nationals to their original countries. Only illegal refugees can be returned and readmitted. The refugees who are under international protection or who are given asylum cannot be returned. In the EU, the member states have decided to sign readmission agreements with third countries in 1994. The guiding principles related to the implementation of these agreements were adopted in 1995. Upon the signing of a readmission agreement, the contracting parties accept to readmit their own nationals who are residing illegally on the territory of the other party or the third country nationals who have crossed their borders illegally to reach the territory of the other party (European Commission, 2015b).

\section{The European Union Readmission Agreements (EURAs)}

The EURAs are used by the EU as a way to manage the migration flows into the EU member countries in an effort to fight against irregular immigration. They try to facilitate the return of immigrants to their own countries. The responsibility and competence to manage these issues have been given to the Commission in 1999. Since then the Council has given directives to the Commission to start negotiations with many countries. With the Lisbon Treaty, the conclusion of the EURAs is legally based on the Article 79(3) of Treaty on the Functioning of the EU. But it is already a principle of international law, although customary, that each country should take back its own nationals (European Commission, 2011).

Overall, the EURAs are important tools to fight against illegal migration from third countries. If right incentives are used, they can be successful. Generally, the EURAs help to improve human rights, enhance Europeanization, create new avenues to revive relations and make negotiations possible. With some countries, readmission negotiations take a very long time. With some, it is not even possible to open negotiations. The reasons for this are lack of incentives on the side of the EU and lack of flexibility on the side of the readmitting countries on technical issues. The negotiations with many countries have delayed due to the insistence of the $\mathrm{EU}$ on the inclusion of third country nationals within the scope of the agreements.

\section{Incentives Offered in Return for Readmission Agreements}

Initially, the EU was trying to conclude these agreements without offering anything in return but since these agreements generally have only a 
few benefits for the third countries, these countries ask for something in return. The Russian Federation and Ukraine negotiations had accelerated only when the EU accepted at their demand to negotiate visa facilitation agreements in parallel with the readmission agreements. In the case of Algeria and China, both countries have repeatedly asked for visa measures but the EU has not accepted for various reasons. The Commission recommends that the EU should develop four main incentives at its disposal: 1. Various visa related tools, 2. Financial Assistance, 3. Global approach to migration toolbox and 4. Legal migration. Trade related measures can also be used as incentives to convince a country to sign a readmission agreement (European Commission, 2011).

\section{Visa Facilitation and Visa Liberalization}

At the first instance, readmission agreements and visa liberalization might seem to be contradicting each other. For example, if the EU aims to decrease the number of migrants passing to the EU territory from the Turkish borders, lifting the visa obligation and opening the borders for free travel might not sound logical. When the borders are opened for visa free travel, one might expect a further increase in illegal migration. However; according to an official Commission Document (Commission Staff Working Document, 2009), the implementation of the EU visa facilitation agreements does not lead to a rise in irregular migration from these countries. The countries can still continue to control who has visa and who does not. Besides, visa liberalization helps that country to harmonize and standardize its visa policies with the policies of the EU, enhances cooperation at the borders, helps the intelligence services to trace smugglers and makes it possible to fight them cooperatively. Therefore, it has been possible for the EU to accept that visa liberalization agreements can provide the necessary incentive for readmission agreements without increasing irregular migration (European Commission, 2011). When the non-EU country is not appropriate for visa liberalization due to various reasons like political instability or lack of technical infrastructure, the EU uses visa facilitation agreements which aim to provide visa facilitation especially only to certain part of the society like the businessmen and academic people.

\section{Financial Assistance}

The other incentive used by the EU to convince a country to accept readmission is financial assistance during the implementation of the agreement. For own nationals, countries need funds to reintegrate these people to their society. This should be achieved so that these people will not need to go back to Europe again. For the third country nationals, again these countries need financial help to keep the returned illegal migrants in their 
countries until they are returned to their original countries. Until then they should be able to stay in those countries under European standards. This has already been experienced where the EU has provided funds to those countries which had signed EURAs, in an effort to support reintegration policies and reception capacities of these countries. Financial assistance has very often been requested by various countries like Morocco, Turkey, Ukraine and some Western Balkan countries. The money to be provided comes on top of what is already programmed or promised under other European programs like the Instrument for Pre-Accession Assistance (IPA) or the European Neighborhood and Partnership Instrument. This money can be provided only from the Thematic Programmes for cooperation in the areas of migration and asylum. But it has a small budget and it covers the whole world. So often the EU has used the funds from the existing geographical programs until now (European Commission, 2011).

\section{The EURAs in force or under negotiation}

Until the present, the Commission has negotiated EU Readmission Agreements with Russia, Morocco, Pakistan, Sri Lanka, Ukraine, the Chinese Special Administrative Regions of Hong Kong and Macao, Algeria, Turkey, Albania, China, Former Yugoslav Republic of Macedonia, Serbia, Montenegro, Bosnia-Herzegovina, the Republic of Moldova, Georgia, Cape Verde, Tunisia, Armenia, Azerbaijan, and Belarus. Seventeen of these negotiations have been finalized and the readmission agreements have come into force including the Chinese Special Administrative Regions of Hong Kong and Macau, Sri Lanka, Russia, Ukraine, the Western Balkan countries, the Republic of Moldova, Georgia, Turkey, Armenia, Azerbaijan, Cape Verde and Pakistan (European Commission, 2015b).

All these agreements constitute a part of the grand plan designed by the EU to secure the Schengen area by protecting external borders. The EU has been developing this plan since the beginning of this millennium. However, the refugee crisis has further shown the EU that if the EU is to continue to prosper peacefully, this could not be realized without the cooperation of its neighbours. Furthermore, this crisis has made it evident that Schengen was more than necessary for a successful single market that is the heart of the EU and cooperation on justice and home affairs was a requirement for Schengen to sustain into the future (Delors et al, 2016).

\section{Examples of Visa Liberalization Dialogues with Successful Outcomes}

The EU has initiated visa liberalization dialogues with three Eastern Partnership countries with which it has signed Readmission Agreements; Ukraine, Moldova and Georgia. With these dialogues, the EU has aimed to take the necessary steps towards a long-term goal of visa free travel, 
provided that the conditions for well managed and secure mobility are achieved. The Commission monitors the implementation of these Action Plans through regular progress reports.

Visa liberalization dialogues are an important and effective tool to help countries achieve difficult reforms in the justice and home affairs area due to their huge impact on areas like rule of law and justice reform. The Visa Liberalization Action Plans (VLAPs) are the major tools of this dialogue. The VLAPs are tailor-made for each partner country. They include four basic benchmarks to be achieved: i) document security, including biometrics; ii) integrated border management, migration management, asylum; iii) public order and security; and iv) external relations and fundamental rights. Based on these benchmarks, the adoption of the legislative, policy and institutional frameworks constitutes the 'phase 1' while ensuring the effective and sustainable implementation constitutes the 'phase 2' (European Commission, 2015c).

\section{Visa Liberalization Dialogues with Moldova, Ukraine and Georgia}

The EU-Republic of Moldova Visa Liberalization Dialogue was launched on 15 June 2010. The first Progress Report was published in September 2011, the second one on February 2012, the third one in June 2012, the fourth in June 2013, the fifth and the final one was published in November 2013. Based on Moldova's successful implementation of all the benchmarks of its VLAP, the Commission has proposed the visa free travel of Moldovan citizens to the Schengen area on 27 November 2013. As of 28 April 2014, visa obligation of the Moldovan citizens to travel to the Schengen zone has been abolished (European Commission, 2015c).

The EU-Ukraine Visa Liberalization Dialogue was initiated on 28 October 2008 and VLAP was presented to Ukraine on 22 November 2010. The first Progress Report was published in September 2011, the second in February 2012 and the third one in November 2013. On 18 December 2015, the European Commission announced that Ukraine has met all of its criteria for visa liberalization and in parallel has adopted the sixth and last progress report related to Ukraine's implementation of its VLAP. The next step for the Commission will be to propose to the Council and the European Parliament the lifting of visa requirements for Ukrainian citizens with biometric passports (European Commission Press Release, 2015a).

With Georgia, the same dialogue was launched on June 2012 and VLAP was presented on 25 February 2013. The first Progress Report was published in November 2013, the second in October 2014 and the third in May 2015. On 18 December 2015, the European Commission announced that Georgia has met all the benchmarks required to be fulfilled in its VLAP. Therefore, the Commission will propose in early 2016 to the Council and the 
European Parliament to lift the visa requirements for the Georgian citizens with biometric travel documents (European Commission, 2015d).

\section{Visa Liberalization Dialogues with the EU Candidate and Potential Candidate Countries}

As of December 2009, the citizens of the former Yugoslav Republic of Macedonia, Montenegro and Serbia have been able to travel visa free to the Schengen area. ${ }^{2}$ Citizens of Albania and Bosnia Herzegovina have also achieved visa free travel since December $2010^{3}$. This has served as a very important incentive for these countries to fasten up their reform efforts and advance their accession processes. The EU is continuing to monitor the sustainability of the visa free travel of the citizens of these countries through a post-visa liberalization monitoring mechanism. The EU has also initiated a visa liberalization dialogue with Kosovo on 19 January 2012 and its related roadmap was given on 14 June 2012. The first Progress Report on Kosovo’s implementation of the requirements of the roadmap was published in February 2013 and the second one in July 2014 (European Commission, 2015e). Concerning Kosovo, the European Commission has published Kosovo's third and final Progress Report related to visa liberalization. The Commission has concluded that there are only eight requirements remained by Kosovo to be fulfilled. As soon as Kosovo fulfills these, the Commission will propose the lifting of visa obligations (European Commission, 2015f).

These few examples show that the EU has been using the readmission agreements as part of its migration policy for the last couple of years. These examples are very important to show how visa facilitation agreements are being used by the EU as an incentive for the realization of readmission agreements. The successful realization of visa liberalization with some of these countries prove that the EU has the capacity to put promises into action.

After describing the importance of the readmission agreements for the EU and giving some examples of such agreements with visa liberalization outcomes, the following section aims to examine the EUTurkey Readmission Agreement as well as the Visa Liberalization Dialogue as being an important incentive tied to the successful implementation of this Agreement. Consequently, the effects of this Agreement and the refugee crisis on EU-Turkey relations will be analyzed.

\footnotetext{
${ }^{2}$ Council Regulation (EC) No 539/2001.

3 http://europa.eu/rapid/press-release_MEMO-10-548_en.htm?locale=en (Accessed on 17.01.2016).
} 


\section{A Short Overview of EU-Turkey Relations}

Turkey has applied for membership to the European Economic Community in 1959. The Association Agreement (Ankara Agreement) between the two parties was signed in 1963. 1970s and the beginning of 80s had been tough years for Turkey both economically and politically. Starting from the second half of 80s onwards, Turkey has worked to liberalize its economy and strengthen its democracy. In 1996, the EU-Turkey Customs Union Agreement came into force. In December 1999 at the Helsinki Summit, Turkey's official candidacy status was given. When Turkey was able to meet the Copenhagen Criteria in 2004, accession negotiations was finally opened on 3 October 2005. The first chapter was opened for negotiations in 2006 and on the same day it has been provisionally closed. However, this new era in the relations between the EU and Turkey has immediately been shadowed when Turkey was asked to put into force the Additional Protocol which would update the Ankara Agreement by including the new ten members of the EU who had become members during the enlargement of 2004. Within these countries Southern Cyprus was also included as one of the new members of the EU, however; Southern Cyprus was not being recognized by Turkey due to the divided status of the island. The EU Council warned Turkey in 2005 to implement the Protocol and realize its responsibilities emanating from this Protocol by opening Turkish ports and airports to the ships and planes of Southern Cyprus. When Turkey has not taken any steps in this direction, in December 2006, the EU Council announced that eight chapters in the accession negotiations were blocked that they would not be opened for negotiations until Turkey abides by its responsibilities under the Protocol and that no chapter would be provisionally closed. In a nutshell, Turkey's implementation of the Additional Protocol has become an opening benchmark for eight chapters while it has become a closing benchmark for all the chapters. In spite of these restrictions, accession negotiations have continued and in 2007 five more chapters, in 2008 four more, in 2009 two more, in 2010 one more chapter and lastly this year one more chapter have been opened to negotiations knowing that none of them could be closed not even provisionally.

Another restriction on the opening of new chapters has come from France. The then French President Nicholas Sarkozy, opposing the full membership of Turkey to the EU, proposed a 'privileged partnership' for Turkey instead of full membership. Therefore, in an effort to prevent Turkey's full membership, France blocked the opening of five additional chapters to negotiations in 2007 which were related to full membership. In addition to these, six more chapters have been blocked by Southern Cyprus in 2009. Between 2010 and 2013, the EU has become preoccupied with the 
financial crisis and the accession negotiations have stalled. 2013 has been a year that has witnessed a revival of relations. With the new French President François Hollande, it has been possible to open one of the chapters (Chapter 22 Regional Policy) that had been previously blocked by France. Again in 2013, the EU-Turkey Readmission Agreement has been signed with the promise of visa liberalization for the Turkish citizens. However; in the following months, the relations have slowed down again. During this period, Euroscepticism in both parties have increased and they have drifted further apart from each other.

It was within this atmosphere that in 2015, the refugee crisis has led to the opening of a new period in EU-Turkey relations. It is possible to argue that the refugee crisis has made the EU to remember the importance of its relations with Turkey and led to a rapprochement in relations. While the EU was in need of Turkish support to stop the flow of refugees to the EU, Turkey was willing to revitalize its accession negotiations. This has helped the parties to compromise. On 29 November 2015, the parties have come together for a summit which has been the culmination of this compromise. The EU has accepted to open up new chapters to revive the relations together with some other incentives which will be discussed below and Turkey has accepted to cooperate with the EU to stop the refugee flows to Europe. Based on this compromise, on 14 December 2015, Chapter 17 (Economic and Monetary Policy) has been opened to negotiations which was again previously blocked by France. However; the success of this rapprochement is based on the performance of the parties in keeping their promises.

Until the beginning of 2016, in the EU-Turkey accession negotiations, 15 chapters out of 35 have been opened to negotiations. The negotiations to open 9 chapters are continuing in the European Council. Among these, the Chapter on justice, freedom and security (Chapter 24) covers migration, asylum, visa policy, external borders, Schengen, judicial cooperation in criminal and civil matters, police cooperation, fight against organized crime, terrorism, drugs, customs cooperation and counterfeiting of the euro. Even though, accession negotiations have not started on this chapter, the EU regularly monitors Turkey's achievements with respect to this chapter through the annual progress reports. The EU also supports Turkey's actions related to this field through the instrument for PreAccession Assistance (IPA). Although Chapter 24 is directly related to the recent migration problems, it does not seem possible to open this chapter because of the veto of Southern Cyprus. 


\section{The EU-Turkey Readmission Agreement and the Visa Liberalization Dialogue (16 December 2013)}

The Council has adopted a decision to initiate negotiations for a EUTurkey Readmission Agreement on 28 November 2002. Negotiations were formally opened on 27 May 2005. Several rounds of negotiations have taken place between the two parties. The EU-Turkey Readmission Agreement has been signed on 16 December 2013 and at the same time the Visa Liberalization Dialogue has been initiated. The readmission obligations under this agreement are reciprocal, these obligations comprise illegal migrants who are own nationals as well as third country nationals and stateless persons (European Commission, 2013a), (European Commission, 2013b).

\section{The Roadmap towards a Visa-Free Regime}

Although Chapter 24 Justice Freedom and Security has not been opened for accession negotiations yet, on 16 December 2013, the EU-Turkey Readmission Agreement has been signed and a visa liberalization dialogue has been started. Based on this dialogue, a roadmap ${ }^{4}$ towards visa-free regime with Turkey has been prepared. This roadmap lists the reforms or areas to be developed and policies to be implemented by Turkey. Accordingly, the Commission will be publishing Progress Reports to evaluate Turkey's performance related to these benchmarks and the Justice and Home Affairs Council will assess the progress made by Turkey every six months. When Turkey fulfils the requirements of the roadmap, the Commission will present its proposal to the European Parliament and the Council to lift the visa obligation for Turkish citizens who hold biometric travel documents. Then, the European Parliament and the Council shall make a decision in accordance with the ordinary legislative procedure based on Article 77 (2)(a) of the Treaty on the Functioning of the EU. The first report on Turkey's progress in fulfilling the requirements of the visa roadmap has been published in October 2014 (European Commission, 2015e).

The roadmap identifies the necessary legislation and administrative reforms that Turkey should achieve to establish a secure environment for visa-free travel to the Schengen area. It brings four basic benchmarks, almost the same with those of Moldova, Ukraine and Georgia. These benchmarks are: 1. Documents security, 2. Migration and border management, 3. Public order and security and 4. Fundamental rights. The Roadmap also includes the

\footnotetext{
4 For the document, see http://ec.europa.eu/dgs/home-affairs/what-isnew/news/news/docs/20131216-roadmap_towards_the_visafree_regime_with_turkey_en.pdf (Accessed on 17.01.2016).
} 
readmission of illegal migrants. In the official document, it has been emphasized that:

This dialogue is tailor-made to allow Turkey to focus its reform efforts and fulfil the EU's requirements. The pace of movement towards visa liberalization will depend on Turkey's progress in adopting and implementing the measures and fulfilling the requirements set out in this Roadmap, including full and effective implementation of the readmission agreement and effective cooperation vis-à-vis all EU Member States on JHA issues as these issues are outlined in the present roadmap (European Commission, 2013b).

An exact date has not been given for visa liberalization but rather its finalization has been based on Turkey's performance in implementing the readmission agreement, fulfilling the other benchmarks in the roadmap and cooperating effectively with all the EU member states on JHA issues.

Following these developments, relations has really slowed down as Euroscepticism both in the EU member states and in Turkey have risen. Upon this background, the Summit that has been realized on 29 November 2015 can be seen as an important date in EU-Turkey relations symbolizing a rapprochement. It is quite evident that the push factor leading to this rapprochement has been the refugee crisis and consequently the emergence of Turkey as a vital actor in EU's struggle with this crisis.

Within the emergency plan of the EU to cope with this crisis, the EUTurkey Readmission Agreement had an important place. The reason for this is that more than two million people running away from the conflict in Syria have been hosted by Turkey. In 2015, around 750.000 of these people, including asylum seekers and economic migrants, have reached Europe over Turkey. (European Commission Press Release, 2015b). If they are not stopped, this number can easily and very quickly rise further up.

It was within this atmosphere that the EU has offered Turkey to draw back the dates of the EU-Turkey Readmission Agreement that was signed in 2013. To convince Turkey in this respect, the EU has used both the visa and the financial support incentives as well as revitalization of the accession negotiations through the promises of opening new chapters.

\section{The EU-Turkey Joint Action Plan - 15 October 2015}

The EU-Turkey action plan accepted on 15 October 2015 aims to establish collaboration between EU and Turkey to supplement Turkey's efforts to manage the influx of Syrian refugees in need of temporary protection. This action tried to create an understanding of burden sharing. This plan also included the other commitments of both parties like visa 
liberalization dialogue for Turkey (European Commission Press Release, 2015c).

In the first part of the plan the EU aims to support the Syrians under temporary protection and their Turkish hosting communities. The EU appreciates Turkey's efforts and emphasizes that Turkey has been hosting almost about 2.2 Syrian refugees since conflict in Syria has emerged and that Turkey has already spent around $€ 7$ billion of its own resources to address this crisis (European Commission Press Release, 2015c).

Under this joint action plan, the EU has intended to mobilize new funds outside the IPA funds that is planned to be allocated to Turkey, to help Turkey cope with the refugees, most notably through the EU Trust Fund for the Syrian crisis. Turkey has intended to effectively implement the law on foreigners and international protection by adopting secondary legislation, make sure that the migrants are registered, have access to public services like education, health and participation in the economy. On the second part of the plan, strengthening cooperation to prevent irregular migration is emphasized. Besides, the visa liberalization dialogue, the visa roadmap and the provisions of the EU-Turkey Readmission Agreement have been described (European Commission Press Release, 2015c).

\section{EU-Turkey Summit - 29 November 2015}

The Commission presented this Joint Action Plan to the Council on 15 October 2015. The Council endorsed this plan and convened an EUTurkey Summit on 29 November 2015. This Summit has activated the Action Plan and re-energized the EU-Turkey relations. At this Summit, the EU has committed itself to increasing political engagement with Turkey, providing significant financial support to Turkey, accelerate the fulfilment of the visa liberalization roadmap and re-energize the accession process (European Council, 2015).

In this Summit, both the EU-Turkey Readmission Agreement and the Visa Liberalization Dialogue have been updated to be finalized at an earlier date. Under the new circumstances, the Readmission Agreement is aimed to be implemented in June 2016 and accordingly visa obligations of Turkish citizens is to be lifted by October 2016 if Turkey has fulfilled its responsibilities related to the Roadmap Towards a Visa-Free Regime by that time. Besides, the EU has promised Turkey to provide $€ 3$ billion financial support for readmission activities covering both its nationals as well as third country nationals especially Syrians. Last but not least, a new chapter, previously blocked by France, has been decided to be opened to negotiations. This was realized on 14 December 2015 by the opening of Chapter 17 on Economic and Monetary Policy to negotiations. The opening of a new chapter after almost two years as well as the Summit with the promises of 
visa free travel to the Schengen area and financial support in the name of burden sharing have revitalized the relations between the EU and Turkey and have created momentum for the stalled accession negotiations. Besides, it has been noted that the EU Commission was committed to achieving the preparatory works for the opening of a number of chapters without prejudice to the position of the member states (European Council, 2015).

In the joint statement that parties have made after this summit, it was emphasized that they were "determined to confront and surmount the existing risks and threats in a concerted manner to reinforce the European Project" (General Secretariat of the Council, 2015). It was accepted that Turkey's accession negotiations should be re-energized. To explore the vast potential of EU-Turkey relations, more frequent high-level dialogue was necessary, therefore, they have agreed on two regular summits a year which would make it possible to assess the developments of relations. In addition to all these, a high level economic dialogue is also planned to be launched in the first quarter of 2016 to improve economic and business relations. The parties have agreed to hold the second meeting of High Level Energy Dialogue and Strategic Energy Cooperation again in the first quarter of 2016. The launch of negotiations to upgrade the Customs Union towards the end of 2016 has also been planned (General Secretariat of the Council, 2015). This has also become a very important topic within the EU-Turkey relations. Based on the structure of the existing EU-Turkey Customs Union Agreement, Turkey stays out of the Transatlantic Trade and Investment Partnership (TTIP) aimed to be signed between the EU and the United States (US) for the establishment of a huge free market. Due to the nature of the existing Customs Union, Turkey is required to open its customs to the US under the mandate of the TTIP, however; the US is not required to do the same thing in return. This leaves Turkey at a disadvantage. As a result, Turkey aims to overcome this situation on an equitable basis by a revision of the existing Customs Union Agreement (Bal, 2014).

"A multi-tier and/or multi-speed Europe seems to emerging de facto in the EU" (Eralp, 2014:7). Within the new flexibility formulations for the future of the EU, Turkey might be able to find a place for itself within the EU. But this can be achieved if the existing vetoes on some of the chapters of the accession negotiations can be overcome so that the negotiations can be continued on a normalized and just accession path way. Therefore, even though the recent developments establish the basis of a rapprochement between the EU and Turkey, the success of this new period depends on its capacity to normalize the relations between the two parties by overcoming the impasse, eliminating the vetoes and enhancing the accession process. Otherwise, this rapprochement can only symbolize a small parenthesis within 
the problematic relationship between the EU and Turkey with the impasse continuing into the future and cutting all the efforts for mutual cooperation.

For the relations to continue into the future in a positive way, there are important responsibilities for both parties. First of all, Turkey should fulfil its obligations emanating from the recent agreements. In parallel with this, the EU should also keep its promises both in terms of financial support and visa liberalization. Many people in Turkey do not believe in the EU's promise of abolishing visa for the Turkish citizens. Rather, they argue that the most that the EU can achieve for Turkey could be visa facilitation but not liberalization. Looking back at the EU-Turkey relations in the past, many Turkish people argue that the EU is not trustable, that it uses double standards and it can easily break its promises by creating new obstacles. If the same thing happens related to the promises of either financial support or visa liberalization, in other words if the EU does not keep its promises duly, the relations between the two parties might become even worse.

The recent economic and political developments in the region and in the world have reminded both parties of their importance for each other. The developments in the Middle East specifically in Syria and the refugee crisis, the terrorist attacks and the threats of terrorists crossing the EU borders, a more assertive Russia, the new energy resources in the Eastern Mediterranean and Africa, the EU's energy security issues and Turkey's strategic location in this respect, the still continuing economic crisis in the EU, the EU's weakening place in the global markets and its competition with the rising economies of the world are just few factors behind the reason why both parties have remembered how they were actually important for each other. Presently, it has become possible to argue that the world politics is striving for a new balance both at the international and regional levels. In this new balance, both the EU and Turkey need each other just like they have needed each other right after the Second World War when a new balance was being established.

In this respect, the EU-Turkey Readmission Agreement and together with it, the promise of visa liberalization, financial support and opening of new chapters in the accession negotiations might be seen as a tipping point in their relationship. Based on the outcomes of these bilateral promises, in other words according to whether they will be kept or not, the relationship will either improve very quickly to the favor of both parties or the impasse will deepen further with increasing lack of trust as the parties will drift apart from each other which will not be beneficial for both of them.

Looking at the previous examples of readmission agreements that the EU has signed and the visa liberalization dialogues it has initiated and finalized, there is enough evidence and hope for Turkey and the Turkish people believe in the realization of visa travel to the EU. Put on top of this 
the opening of new chapters and financial support which would then constitute the beginning of a new era in the relations between the EU and Turkey nurtured by trust.

\section{Analysis and expectations}

The developments in the Middle Eastern region starting with the Arab Spring have led Turkey to emerge as a very important actor. From Turkey's point of view, the increasing instability in the region together with Turkey's increasing isolation have led Turkey to rethink about its relations with the EU (Eralp, 2014). For the EU, Turkey is located at a very strategic place between the EU and the instable region. Therefore, both parties have favored rapprochement. The important point lies at the juncture whether this rapprochement will be able to overcome the long standing impasse in the relations or not. If the impasse in the relations resulting from Turkey's not implementing the requirements of the Additional Protocol concerning Southern Cyprus and the EU's vetoes to impede the accession negotiations are not eliminated, then this rapprochement is doomed to be very short lived. At the present, the underlying factors concerning the impasse have not disappeared yet. As long as the vetoes continue on the accession negotiations, opening of one or two chapters, although good news, does not mean much. Besides, there is a serious credibility problem. Many Turkish people have lost their belief in Turkey's membership. They do not foresee full membership. They do not trust the EU as a partner and they think that Turkey is being seduced by the EU through the promises that will never be realized or kept. The fact that the EU-Turkey accession negotiations can easily be blocked by the wish of a single country frustrates the Turkish people and creates negative sentiments about the EU. Turkish people find it difficult to understand how the EU member states accept to be dictated by the specific wishes of a single country and none of them oppose this (Eralp, 2014). Therefore, this rapprochement can really mean something if it leads to an era of trust and cooperation for mutual benefits between the parties.

A recent example might be sufficient to explain the credibility problem. Chapter 17 (Economic and Monetary Policy) has been opened to negotiations on 14 December 2015 as part of the promises made by the EU concerning the refugee crisis. In fact, the EU has decided to open this chapter to negotiations and has invited Turkey with an official letter from the German Presidency of the EU in 2007, to submit its Document related to its negotiation position. Turkey has submitted its position in March 2007. However; France has decided to block the opening of this chapter after Turkey's submission. This has demonstrated clearly that the official letters of the EU Presidency as well as the unanimous decisions of the EU can easily be nullified by one single country (Eralp, 2014: 5). On Turkey’s side, this 
has had the effect of decreasing confidence in the EU, strengthening the belief that the EU might not hold its promises. Upon this development that has taken place in 2007, the opening of Chapter 17 to negotiations has been a positive step forward, however; it is not enough to overcome the EU's long standing credibility problem in Turkey.

In this respect, the successful finalization of the EU-Turkey Readmission Agreement and visa liberalization would be very important achievements for the EU-Turkey relations in terms of reestablishing trust among the parties. However; these topics are the contents of Chapter 23 on Judiciary and Fundamental Rights and Chapter 24 on Justice, Freedom and Security which are closely related to readmission and visa freedom. Unfortunately, these two related chapters are presently blocked under the veto of Southern Cyprus. This means that even though a new era has begun between the EU and Turkey with cooperation on a new avenue, as long as the vetoes continue, it is not possible to proceed in this new avenue with a future vision aimed at finalizing negotiations and closing these chapters. Given that the existing vetoes continue, these developments then; the readmission agreement, the visa liberalization and the opening of a new chapter, cannot have much contribution for the future of Turkey's membership in the EU. They rather seem to be a part of the firefighting strategy of the EU to stop the refugee flows to Europe.

Actually, this rapprochement represents a very important and historical point in time since the needs of both parties have coincided to produce compromise in problematic areas. If these problematic areas can be solved within this limited time by the good will and credible actions of both parties, this rapprochement can really become the beginning of a new era between the EU and Turkey.

Under these circumstances, for the vetoes to be eliminated; either the Cyprus problem should be resolved very fast to open up the way forward for Turkey in its relations with the EU or other ways or formulas should be developed to overcome these vetoes and make Turkey's accession possible. Finally, a clear plan or a timetable should be presented to Turkey that can motivate it for further reform and cooperation with the EU. For all these to be realized, there is a great need of trust in the relationship. The new seeds of partnership based on the recent conjuncture should be built around compromise to establish a new atmosphere and to start a new phase in the bilateral relations. The recent developments in the region and in the world show that the two parties will be in need of each other in an increasing scale in the years to come and it is now the time to reestablish this relationship free from the imperfections of the past with a strong emphasis for a successful future cooperation. 
In the history of the EU, it has been possible to witness that the European countries have been able to integrate faster when they have confronted a common threat. European integration has almost been the outcome of uniting against common threats. It is possible to see the same pattern when it comes to the EU's relations with Turkey. Faced with common threats, parties might find it mutually more beneficial to deepen relations and integrate further.

\section{Conclusion}

During the post Second World War era, Turkey has established its relations with the West based on the communist threat. The West has offered economic and security support to Turkey with the Marshall Plan and membership in NATO within the structure of its containment policy towards communism. Turkey's relations with Europe has been shaped within this understanding. Presently, migration has become a top policy issue, especially in 2015, and it seems like it will continue to be so in the near future. Under this circumstance, the EU seems to be in an effort to improve its relations with Turkey on the basis of containing the refugees flowing from Syria and the Middle East to Europe. Turkey once more has become a very important ally for the EU due to its strategic location in the refugee crisis.

The refugee crisis has put an immense pressure on EU's Schengen policy. Schengen is one of the greatest achievements of the EU that supports the single market. Losing Schengen would greatly damage the single market which is at the heart of the European project. Therefore; stopping the refugees who are threatening Schengen and the single market is a vital need for the EU.

This said, the refugee crisis has led to a rapprochement between Turkey and the EU. The EU has remembered once more the important strategic place of Turkey for Europe. On the other hand, Turkey has gotten the opportunity to test the EU once again whether their relationship can recover and develop in the future. This very important time period might lead to the flourishing of cooperation between Turkey and the EU or it might end up with an even deeper impasse drifting the parties further away from each other. Therefore, it is very important for Turkey to implement the Readmission Agreement fully and for the EU to keep its promises duly. If the EU does not keep its promises, then Turkey might stop implementing the Readmission Agreement or vice versa, if Turkey does not implement the Readmission Agreement, then the EU might not keep its promises. Both ways would end this rapprochement which would be to the disadvantage of both parties. If the EU can prove that its plans for Turkey are for a longer term cooperation, a productive era in the relations might start which can be mutually beneficial. The refugee crisis has clearly shown the EU leaders that 
the future of the EU cannot be thought of without the cooperation with Turkey. As for Turkey, optimism about the possible outcomes of recent developments should continue on a cautious basis and EU's promises should not be taken for granted.

\section{References:}

BAL, Pinar (2014), “The Effects of the Transatlantic Trade and Investment Partnership on the European Union and Turkey”, International Conference on Eurasian Economies, Skopje, Macedonia, 1-3 July 2014.

BAYRAKLI, Enes and KESKİN, Kazım (2015, November), "Türkiye, Almanya ve AB Üçgeninde Mülteci Krizi”, SETA, İstanbul. http://file.setav.org/Files/Pdf/20151221191329_turkiye-almanya-ve-abucgeninde-multeci-krizi-pdf.pdf (Accessed on: 09.01.2016).

CARRERA, Sergio; BLOCKMANS, Steven; GROS, Daniel and GUILD, Elspeth (2015, December 16), “The EU's Response to the Refugee Crisis: Taking Stock and Setting Policy Priorities”, Centre for European Policy Studies (CEPS) Essay, 20. https://www.ceps.eu/system/files/EU\%20Response\%20to\%20the\%202015\% 20Refugee\%20Crisis_0.pdf (Accessed on: 09.01.2016).

Commission Staff Working Document of (2009, October 15), "Evaluation of the implementation of the European Community's visa facilitation agreements with third countries" SEC (2009) 1401 final. http://ec.europa.eu/transparency/regdoc/rep/2/2009/EN/2-2009-1401-EN-F0.Pdf (Accessed on: 02.01.2016).

CRISP, James (2015, April 27), “Juncker suffers double blow on immigration at summit”, Euractiv. http://www.euractiv.com/sections/globaleurope/juncker-suffers-double-blow-immigration-summit-314053 (Accessed on: 07.01.2016).

DELORS, Jacques; VITORINO, Antonio and BERTONCINI, Yves (2016, January 7), "Schengen is dead? Long live Schengen!”, Jacques Delors Institute, Euractiv. http://www.euractiv.com/sections/justice-homeaffairs/schengen-dead-long-live-schengen-320730 (Accessed on 07.01.2016).

ERALP, Nilgün Arısan (2014), “The Outlook for EU-Turkey Relations”, (Ed.) Timothy Reno, In Turkish Policy Brief Series, 12th edition, International Policy and Leadership Institute (IPLI) - Economic Policy Research Foundation of Turkey (TEPAV). http://www.tepav.org.tr/upload/files/1390554733-

6.The_Outlook_for_EU_Turkey_Relations.pdf (Accessed on: 22.01.2016). European Commission (2015a, December 17), Migration and Home Affairs, "Irregular Migration and Return”. http://ec.europa.eu/dgs/home- 
affairs/what-we-do/policies/irregular-migration-return-policy/index_en.htm (Accessed on: 08.01.2016).

European Commission (2015b, May 6), Migration and Home Affairs. "Return and Readmission". http://ec.europa.eu/dgs/home-affairs/what-wedo/policies/irregular-migration-return-policy/return-

readmission/index_en.htm (Accessed on: 07.01.2016).

European Commission (2015c), Migration and Home Affairs, "Moving towards visa liberalization with Moldova, Ukraine and Georgia”. http://ec.europa.eu/dgs/home-affairs/what-we-do/policies/internationalaffairs/eastern-partnership/visa-liberalisation-moldova-ukraine-andgeorgia/index_en.htm (Accessed on 17.01.2016).

European Commission (2015d, December 18), Report from the Commission to the European Parliament and the Council, Fourth progress report on Georgia's implementation of the action plan on visa liberalization, COM (2015) 684 final, Brussels, 18.12.2015. http://ec.europa.eu/dgs/homeaffairs/e-library/documents/policies/international-

affairs/general/docs/fourth_report_georgia_implementation_action_plan_vis a_liberalisation_en.pdf (Accessed on: 17.01.2016).

European Commission (2015e), Migration and Home Affairs, "Enlargement”. http://ec.europa.eu/dgs/home-affairs/what-wedo/policies/international-affairs/enlargement/index_en.htm (Accessed on 17.01.2016).

European Commission (2015f, December 18), Report from the Commission to the European Parliament and the Council, third report on progress by Kosovo in fulfilling the requirements of the visa liberalization roadmap, COM (2015) 906 final, Brussels, 18.12.2015.

European Commission (2013a, December 16), “EU-Turkey Readmission Agreement signed and Visa Liberalization Dialogue launched”, Migration and Home Affairs, News. http://ec.europa.eu/dgs/home-affairs/what-isnew/news/news/2013/20131216_01_en.htm (Accessed on 16.01.2016).

European Commission (2013b, December 16), Migration and Home Affairs, "Roadmap Towards a Visa Free Regime with Turkey". http://ec.europa.eu/dgs/home-affairs/what-isnew/news/news/docs/20131216-roadmap_towards_the_visafree_regime_with_turkey_en.pdf (Accessed on 17.01.2016).

European Commission (2011, February 2), Communication from the Commission to the European Parliament and the Council, Evaluation of EU Readmission Agreements, COM (2011) 76 final, Brussels. http://ec.europa.eu/dgs/home-

affairs/news/intro/docs/comm_pdf_com_2011_0076_f_en_communication.p df (Accessed on: 07.01.2016). 
European Commission Press Release (2015a, December 18), Commission Progress Report: Ukraine meets criteria for visa liberalization, IP/15/6367. http://europa.eu/rapid/press-release_IP-15-6367_en.htm (Accessed on 17.01.2016).

European Commission Press Release (2015b, December 15), “Commission presents Recommendation for a Voluntary Humanitarian Admission Scheme with Turkey for refugees from Syria". http://europa.eu/rapid/pressrelease_IP-15-6330_en.htm (Accessed on: 08.01.2016).

European Commission Press Release (2015c, October 15), “EU-Turkey joint action plan”. Fact Sheet. http://europa.eu/rapid/press-release_MEMO-155860_en.htm (Accessed on: 08.01.2016).

European Council (2015, November 29), Meeting of Heads of State or Government with Turkey, EU-Turkey Statement, 29.11.2015. Press releases and Statements. http://www.consilium.europa.eu/en/press/pressreleases/2015/11/29-eu-turkey-meeting-statement/ (Accessed on: 01.02.2016).

General Secretariat of the Council, Press Office (2015, November 29), "Meeting of heads of state or government with Turkey - EU-Turkey statement”, International Summit, Press EN, Statements and Remarks, 870/15, 29.11.2015. http://www.consilium.europa.eu/press-releasespdf/2015/11/40802205539_en_635846527200000000.pdf (Accessed on: 07.01.2016).

GOTEV, Georgi (2015, April 23), "EU leaders to declare: 'We cannot take more migrants'”, Euractiv. http://www.euractiv.com/sections/globaleurope/eu-leaders-will-say-we-cannot-take-more-migrants-314027

(Accessed on 07.01.2016).

GÖNEN, Emre (2016, January 12), “And now what future for the refugees in the EU?”, Daily Sabah Columns. http://www.dailysabah.com/columns/emre_gonen/2016/01/12/and-nowwhat-future-for-the-refugees-in-the-eu (Accessed on: 25.01.2016). 